\title{
Attitudes towards mental illness in the Commonwealth of Dominica
}

\author{
Robert Kohn, ${ }^{1}$ David Sharma, ${ }^{2}$ Christopher P. Camilleri, ${ }^{3}$ \\ and Itzhak Levav ${ }^{4}$
}

ABSTRACT Little is known about the perception of mental illness in the English-speaking Caribbean. This study was conducted in 1995 to determine the attitudes, knowledge, and help-seeking practices for emotional disorders in the Commonwealth of Dominica. Two groups in Dominica were surveyed: 67 community leaders, consisting of nurses, teachers, and police officers; and 135 community members grouped into five socioeconomic strata that were collapsed to three for the analysis. All the respondents were asked to identify and suggest management of individuals with psychosis, alcoholism, depression, and childhood hyperactivity, as depicted in case vignettes. The person in the psychosis vignette was diagnosed as suffering from mental illness by $84.0 \%$ of the leaders and by $71.2 \%$ of the community members. However, in each of the three other vignettes, fewer than $30 \%$ of the respondents thought that mental illness was present. The person with alcoholism was viewed as having a serious problem by only slightly more than half of the respondents. Fewer than half of the respondents thought that the individuals with depression or hyperactivity had serious problems. The community leaders did somewhat worse in recognizing mental illness than did the community members. Respondents were most likely to refer a family member with emotional problems to a medical practitioner. In conclusion, education about mental health problems is needed in Dominica. Especially disconcerting was the lack of knowledge on mental illness among nurses, teachers, and police officers, that is, professionals directly involved in the pathway to care.

Dominica is of the largest of the Windward Islands. It is located in the Eastern Caribbean between the French islands of Guadeloupe and Marti-

\footnotetext{
1 Butler Hospital, Providence, Rhode Island, United States of America, and Brown University, Department of Psychiatry and Human Behavior, Providence, Rhode Island, United States of America. Send correspondence to: Robert Kohn, M.D., Butler Hospital, 345 Blackstone Blvd., Providence, RI 02906, USA. Tel: 401/455-6277; fax: 401/455-6566; e-mail: Robert_Kohn@brown.edu

2 Department of Psychiatry, Princess Margaret Hospital, Dominica, West Indies.

3 Harvard South Shore Department of Psychiatry, Veterans Administration Medical Center, Brockton, Massachusetts, United States of America.

4 Pan American Health Organization, Washington, D.C., United States of America.
}

nique. Dominica has a population of over 71000, of whom 16000 reside in Roseau, the capital. A former British colony, Dominica gained its independence in 1978. Although only 29 miles long and 16 miles wide, its mountainous terrain makes access to the capital difficult for most of the villagers. The country is predominately Roman Catholic. Dominica has the only surviving Carib indigenous population, estimated at some 2000 persons. Although English is Dominica's official language, the majority of the population also speak French Creole. While the island's economy is based primarily on agriculture, the country is not self-sufficient in food production.
A 1995 poverty assessment survey for Dominica showed that $27 \%$ of households live in poverty and are unable to adequately meet basic needs, including nutritional ones (1). However, undernutrition of young children is extremely low, at a rate of $1.4 \%$. The unemployment rate is estimated to be approximately $9.9 \%$. Although there is no compulsory education, in $199391.6 \%$ of the population between the ages of 5 and 19 were registered in school. Primary school has been completed by $67.1 \%$ of the population. The functional illiteracy rate is estimated to be $10.5 \%$.

A well-developed primary care system serves each of Dominica's ten parishes, or administrative divisions. 
Recent legislation to reform the health care delivery system introduced national health insurance in the country.

Since 1993, technical collaboration by the Mental Health Program of the Pan American Health Organization and the World Health Organization Collaborative Center in Montreal, Canada, has aided in the development of a network of mental health care services reaching even the most remote villages.

According to Dominica's 1995 Mental Health Report, the age-adjusted incidence of schizophrenia was $0.9 \%$ (1). In that same year, there were a total of 2166 psychiatric outpatient visits. Inpatient psychiatric treatment is available in the capital, at the Princess Margaret Hospital. Of that hospital's 652 inpatient psychiatric admissions in $1995,8.7 \%$ were due to alcoholism, $7.6 \%$ to cannabis psychosis, and $2 \%$ to cocaine abuse. The Mental Health Report also concluded that $90 \%$ of the patients in the prison psychiatric clinic had a history of drug abuse. The country's mental health policy is currently being reformulated to address service needs and legal issues.

Little is known about the perception of mental illness in the English-speaking Caribbean. Such information is important since lay attitudes toward mental disorders and the persons suffering from them influence help-seeking behavior and compliance with treatment (2). Individuals with a mental disorder at least initially share the same beliefs about mental illness as do the other members of their society. These attitudes help determine when persons will seek help and how they will later be reintegrated into the community $(3,4)$.

The aim of this study was to determine the knowledge, perceptions, and attitudes towards mental illness and help-seeking behavior in reference to psychiatric care.

\section{MATERIALS AND METHODS}

\section{Study population}

This study was conducted in April 1995 on a nonrandomized sample from the various communities around the island. Two groups were selected for study.

The first group was comprised of community leaders: nurses, teachers, and members of the police force. Because of their positions and visibility, these "gatekeepers" have frequent contact with individuals with emotional problems. Eighty questionnaires were sent to the chief education officer for distribution to teachers from various schools around the island, and $42.5 \%$ of those questionnaires were returned. The office of the chief public health nurse distributed 140 questionnaires to nurses at the health centers around the island, but only $10.7 \%$ were returned. Of the 110 questionnaires distributed from the office of the commissioner of police to police at stations around the island, slightly over $16 \%$ were returned. In total, 67 out of 330 questionnaires were returned, yielding a modest $20.3 \%$ response rate.

The second study group consisted of individuals from different communities around the island, who were interviewed face to face by a social worker. The in-person interviews lasted between 10 and 15 minutes. After stratifying by socioeconomic status, 30 subjects were randomly selected by the social worker, with the assistance of health visitors, from the records of community health centers in each of the country's seven health regions. The various communities in the regions were selected by the Dominicabased team to represent both urban and rural areas and to be geographically representative of the Commonwealth's population; selection of the communities was not random.

Information on socioeconomic status (SES) is collected routinely by each community health center during a home assessment done by a health visitor. Determination of SES was based on quality of housing, ownership of property, occupational status, income, availability of running water and toilet facilities in the home, and ownership of such amenities as an automobile and television. SES was divided into five groups based on Hollingshead and
Redlich's scale. ${ }^{5}$ The two lowest and two highest SES groups were collapsed, leaving three groupings.

The overall response rate for the 210 community members was $64 \%$ due to the unavailability of respondents. The 135 community-member respondents included 67 individuals from social classes 1 and 2 (low), 47 individuals from social class 3 (middle), and 21 individuals from social classes 4 and 5 (high).

\section{Questionnaire}

The questionnaire consisted of two parts. The first section included demographic information, as well as items about the emotional health of the informant and the informant's family. The second part contained four case vignettes followed by questions tapping the informant's knowledge, attitudes, and perceptions relating to mental health. The vignettes were those of Star, ${ }^{6}$ with adaptations (5).

The first vignette described an individual who had psychotic symptoms: "Now I want to describe a man called John, who is very suspicious. He doesn't trust anybody, and he's sure that everybody is against him. Sometimes he thinks that people he sees on the street are talking about him or following him around. He has beaten up men who didn't even know him. The other night, he began to curse his wife terrible, then he hit her and threatened to kill her because, he said, she was working against him, just like everyone else."

The second vignette was of an individual with alcoholism: "Carlos never seems to be able to hold a job very long, because he drinks too much. Whenever he has money in his pocket, he goes on a spree. He stays out all hours drinking, and never seems to care what happens to his wife and chil-

\footnotetext{
5 Hollingshead AB. Four factor index of socioeconomic status [mimeo]. New Haven, Connecticut; 1975.

6 Star SA. The public's ideas about mental illness [mimeo]. National Opinion Research Center, University of Chicago; 1955.
} 
dren. Sometimes he feels very bad about the way he treats his family. $\mathrm{He}$ begs his wife to forgive him and promises to stop drinking but always goes off again."

The third vignette depicted a case of depression: "Maria is a 50 -year-old woman who lives with her husband. The neighbors remember her as someone who was happy and took good care of her husband and family. Her three sons have already completed their studies and are married. Though living in different places, they visit on occasion. Maria appears different over the last several years in that all she does is stay home. She speaks slowly and cries, eats and sleeps a little, and appears to be very unhappy."

The last case was of a child with hyperactivity: "Paul is a 12-year-old boy who is in school, but is in a class 3 years behind the other children of his age. He is very active and unable to settle in class. This has been going on since he was a few years old. Recently, he is becoming very restless in class and is becoming involved in fights with other children in the class and at home."

\section{Analyses}

The data were initially analyzed comparing the responses from the community members and the community leaders, with subsequent analyses limited to the community-members sample. In the community-members sample, gender, social class, age of respondents, and the respondent's history of an emotional disorder were examined as predictors for differential attitudes toward mental illness. Categorical data were examined using the chi-square statistic, and continuous data were examined with analysis of variance (ANOVA) and $t$ tests. The analysis was not corrected for multiple comparisons.

\section{RESULTS}

\section{Demographics and health}

Table 1 provides information on the demographic characteristics of the community members and of the community leaders. Table 2 provides additional details on the community-member group, by socioeconomic status.

In response to other questionnaire items, the leader group viewed themselves to be in better physical health than the community-members group did, by a significant margin. Only $21.6 \%$ of the community-member sample thought their health was very good, in comparison to $50.7 \%$ of the leader sample $\left(\chi^{2}=30.34\right.$, degrees of freedom $(\mathrm{df})=3, P<0.00001)$. However, within the community-members group there was a gradient in perceived health, with $42.9 \%$ of the highSES group viewing themselves to be in very good health, versus $19.6 \%$ for the middle group, and $16.4 \%$ for the low group $\left(\chi^{2}=20.03, \mathrm{df}=6, P<\right.$ 0.003).

In terms of having consulted someone for an emotional or nervous problem, there was no significant statistical difference between the communityleaders group and the community- members group; the rate was $9.2 \%$ among the leaders and $17.9 \%$ among the community members. Similarly, there was no statistically significant difference among the three SES groups of the community members, with rates of $22.4 \%$ for the low-SES group, $15.2 \%$ for the middle-SES group, and $9.5 \%$ for the high-SES group, respectively.

With respect to having taken medications for an emotional or nervous problem, there was a statistically significant difference between the communityleader group and the communitymember group, with rates of $4.6 \%$ and $17.2 \%$, respectively $\left(\chi^{2}=6.07, \mathrm{df}=1\right.$, $P<0.02)$. On this questionnaire item, there were no statistically significant differences among the three SES groups of the community members, with rates of $22.4 \%$ for the low-SES group, $15.2 \%$ for the middle-SES group, and $4.3 \%$ for the high-SES group, respectively.

The respondents were asked how often they thought that people with an emotional or nervous problem were violent. Both the community-leader

TABLE 1. Demographic characteristics of the community-member and community-leader groups, Dominica, 1995

\begin{tabular}{|c|c|c|c|}
\hline Variable & $\begin{array}{c}\text { Community } \\
\text { members } \\
(\%) \\
(n=135)\end{array}$ & $\begin{array}{c}\text { Community } \\
\text { leaders } \\
(\%) \\
(n=67)\end{array}$ & Statistic \\
\hline Gender: male & 48.9 & 53.7 & $\chi^{2}=0.42, \mathrm{df}=1,=\mathrm{ns}^{\mathrm{a}}$ \\
\hline Age (years) & $37.0 \pm 14.8^{b}$ & $32.0 \pm 7.5$ & $t=-2.54, \mathrm{df}=196, P<0.02$ \\
\hline Education (years) & $11.0 \pm 3.6$ & $14.4 \pm 5.1$ & $t=-5.17, \mathrm{df}=177, P<0.0001$ \\
\hline Illiteracy & 20.7 & 0 & $\chi^{2}=15.90, \mathrm{df}=1, P<0.00001$ \\
\hline Marital status & & & $\chi^{2}=4.48, \mathrm{df}=5, P=\mathrm{ns}$ \\
\hline Single & 61.2 & 56.7 & \\
\hline Married & 31.3 & 37.3 & \\
\hline Separated/Divorced & 3.0 & 4.5 & \\
\hline Widowed & 3.7 & 0 & \\
\hline Other & 0.7 & 0 & \\
\hline Employment & & & $\chi^{2}=47.91, \mathrm{df}=4, P<0.00001$ \\
\hline Full-time & 43.6 & 96.4 & \\
\hline Part-time & 11.9 & 4.6 & \\
\hline Housewife & 11.9 & 0 & \\
\hline Unemployed & 23.8 & 0 & \\
\hline Not seeking & 8.9 & 0 & \\
\hline Informant head of household & 67.4 & 63.9 & $\chi^{2}=1.15, \mathrm{df}=1, P=\mathrm{ns}$ \\
\hline Number of persons in household & $4.3 \pm 2.6$ & $4.2 \pm 1.9$ & $t=0.27, \mathrm{df}=197, P=\mathrm{ns}$ \\
\hline Number of rooms in household & $3.3 \pm 1.7$ & $4.0 \pm 1.1$ & $t=3.02, \mathrm{df}=190, P<0.003$ \\
\hline
\end{tabular}


TABLE 2. Demographic characteristics of the community-member group by socioeconomic status, Dominica, 1995

\begin{tabular}{|c|c|c|c|c|}
\hline Variable & $\begin{array}{c}\text { Low } \\
(\%) \\
(n=67)\end{array}$ & $\begin{array}{c}\text { Middle } \\
(\%) \\
(n=47)\end{array}$ & $\begin{array}{c}\text { High } \\
(\%) \\
(n=21)\end{array}$ & Statistic \\
\hline Gender: male & 49.3 & 48.9 & 47.6 & $\chi^{2}=0.02, \mathrm{df}=2, P=\mathrm{ns}^{\mathrm{a}}$ \\
\hline Age (years) & $41.8 \pm 15.6$ & $37.3 \pm 13.9$ & $37.0 \pm 15.1$ & $\hat{\mathrm{F}}=0.97, \mathrm{df}=2, P=\mathrm{ns}$ \\
\hline Education (years) & $10.1 \pm 3.0$ & $10.6 \pm 3.1$ & $14.3 \pm 4.5$ & $\mathrm{~F}=12.47, \mathrm{df}=2, P<0.0001$ \\
\hline Illiteracy & 34.3 & 10.6 & 0 & $\chi^{2}=15.94, \mathrm{df}=2, P<0.004$ \\
\hline Marital status & & & & $\chi^{2}=12.49, \mathrm{df}=10, P=\mathrm{ns}$ \\
\hline Single & 68.2 & 59.6 & 42.9 & \\
\hline Married & 22.7 & 34.0 & 52.4 & \\
\hline Divorced/Separated & 1.5 & 4.2 & 4.8 & \\
\hline Widowed & 6.1 & 2.1 & 0 & \\
\hline Other & 1.5 & 0 & 0 & \\
\hline Employment & & & & $\chi^{2}=28.58, \mathrm{df}=8, P<0.0004$ \\
\hline Full-time & 20.0 & 61.8 & 76.5 & \\
\hline Part-time & 12.0 & 14.7 & 5.9 & \\
\hline Housewife & 18.0 & 5.9 & 5.9 & \\
\hline Unemployed & 38.0 & 14.7 & 0 & \\
\hline Not seeking & 12.0 & 2.9 & 11.8 & \\
\hline \multicolumn{5}{|l|}{ Number of persons } \\
\hline Number of rooms & & & & \\
\hline in household & $2.7 \pm 1.4$ & $3.8 \pm 1.7$ & $4.0 \pm 1.6$ & $\mathrm{~F}=6.23, \mathrm{df}=2, P<0.003$ \\
\hline
\end{tabular}

${ }^{a} \mathrm{~ns}=$ not significant.

${ }^{\mathrm{b}}$ Mean \pm standard deviation is used for age, education, and persons and rooms in household. group and the community-member group perceived a potential for violence (leaders versus community-member group: violent all of the time, $3.0 \%$ and $3.8 \%$; some of the time, $83.6 \%$ and $79.7 \%$; rarely, $11.9 \%$ and $14.3 \%$; never, $1.5 \%$ and $2.3 \%$ ).

Both the community-leader group and the community-member group would send a family member who had an emotional problem first to a doctor or hospital, and only later to a psychiatrist or other mental health provider (Table 3).

\section{Vignette 1: psychosis}

Virtually all the questionnaire respondents-98.0\% overall-thought that something was wrong with the individual in the psychosis vignette
TABLE 3. Preferences for referral of a family member with emotional problems, Dominica, 1995

\begin{tabular}{|c|c|c|c|c|}
\hline \multirow[b]{2}{*}{ Referral } & \multicolumn{2}{|c|}{ First choice } & \multicolumn{2}{|c|}{ Second choice } \\
\hline & $\begin{array}{c}\text { Community } \\
\text { members } \\
(\%)\end{array}$ & $\begin{array}{c}\text { Community } \\
\text { leaders } \\
(\%)\end{array}$ & $\begin{array}{c}\text { Community } \\
\text { members } \\
(\%)\end{array}$ & $\begin{array}{c}\text { Community } \\
\text { leaders } \\
(\%)\end{array}$ \\
\hline Doctor & 33.6 & 34.9 & 18.5 & 15.7 \\
\hline Hospital & 15.7 & 17.5 & 19.4 & 15.7 \\
\hline Psychiatrist & 5.2 & 0.0 & 9.7 & 39.2 \\
\hline Nurse & 13.4 & 0.0 & 3.2 & 0.0 \\
\hline Clinic & 12.7 & 7.9 & 1.6 & 0.0 \\
\hline Clergy & 6.0 & 11.1 & 7.3 & 2.0 \\
\hline Counselor ${ }^{\mathrm{a}}$ & 5.2 & 11.1 & 9.7 & 7.8 \\
\hline Other & 7.5 & 17.5 & 20.1 & 13.7 \\
\hline Don't know & 0.7 & 0.0 & 10.5 & 5.9 \\
\hline
\end{tabular}

a "Counselor" includes social worker, psychologist, and welfare counselor.
(Table 4). The leader group, however, identified the vignette as describing an individual with a mental illness at a significantly higher rate than did the community-member respondents, $84.0 \%$ vs. $71.2 \%\left(\chi^{2}=8.85, \mathrm{df}=3, P<0.03\right)$. Both groups found the problem presented in the vignette to be serious regardless of whether or not it was viewed as a mental illness. Of the community-member respondents, $6.2 \%$ thought this individual could overcome his problem on his own, while $3.8 \%$ thought he could not overcome it at all. Only $1.5 \%$ of the leader group thought the individual in the vignette could not overcome his problem at all. Over 30\% of the both the respondent groups thought the person in the vignette had a mental illness and felt he should be in a mental hospital. The most common types of treatment suggested by the community-member respondents, regardless of whether they believed this to be a psychiatric disorder, were: mental hospitalization, $29.0 \%$; psychiatrist, $22.1 \%$; social worker, 10.7\%; and psychologist, 7.6\%. Among the leader group the most common interventions recommended were: psychiatrist, 33.8\%; mental hospital, 27.7\%; psychologist, $26.2 \%$; and social worker, $4.6 \%$. Table 4 provides a summary of the responses.

No differences based on the community respondents' gender were found in knowledge, attitudes, and perception in regards to psychosis. In addition, the respondents' history of emotional or nervous disorder did not significantly affect the results. Among the community-member respondents, older individuals were more likely to believe there was nothing wrong with the person described in the vignette $(t=2.21, \mathrm{df}=131, P<0.03)$. In addition, those in the low-SES group more often felt that the person described needed to be in a mental hospital, $44.4 \%$ versus $26.8 \%$ for the middle-SES group and $16.7 \%$ for the high-SES group $\left(\chi^{2}=14.32, \mathrm{df}=6, P<0.03\right)$.

\section{Vignette 2: alcoholism}

The community leaders more often thought that something was wrong 
TABLE 4. Percent responding yes to selected questions for each vignette, Dominica, 1995

\begin{tabular}{lcc}
\hline \multicolumn{1}{c}{ Question asked } & $\begin{array}{c}\text { Community members } \\
(\%)\end{array}$ & $\begin{array}{c}\text { Community leaders } \\
(\%)\end{array}$ \\
\hline Is something wrong with this individual? & & \\
Vignette 1: Psychosis & 97.0 & 100 \\
Vignette 2: Alcoholism & 85.9 & 98.4 \\
Vignette 3: Depression & 91.1 & 98.4 \\
Vignette 4: Hyperactivity & 90.3 & 87.1 \\
Is this mental illness? & & \\
Vignette 1: Psychosis & 71.2 & 84.0 \\
Vignette 2: Alcoholism & 21.1 & 14.8 \\
Vignette 3: Depression & 25.6 & 18.6 \\
Vignette 4: Hyperactivity & 28.9 & 18.3 \\
Is this a serious problem? & & \\
Vignette 1: Psychosis & 70.2 & 80.6 \\
Vignette 2: Alcoholism & 55.7 & 59.0 \\
Vignette 3: Depression & 49.6 & 30.6 \\
Vignette 4: Hyperactivity & 44.4 & 40.0 \\
If yes mental illness, is help needed? & & \\
Vignette 1: Psychosis & 91.4 & 98.4 \\
Vignette 2: Alcoholism & 92.3 & 96.6 \\
Vignette 3: Depression & 89.1 & 97.3 \\
Vignette 4: Hyperactivity & 83.3 & 96.6 \\
If no mental illness, is help needed? & & \\
Vignette 1: Psychosis & 89.2 & 9.8 \\
Vignette 2: Alcoholism & 82.6 & 98.5 \\
Vignette 3: Depression & 84.7 & 95.1 \\
Vignette 4: Hyperactivity & 84.0 & 91.8 \\
If yes mental illness, need mental hospital? & & 90.2 \\
Vignette 1: Psychosis & 33.6 & \\
Vignette 2: Alcoholism & 13.7 & \\
Vignette 3: Depression & 11.7 & \\
Vignette 4: Hyperactivity & 30.3 & \\
\hline & & \\
\hline
\end{tabular}

with the individual in the alcoholism vignette than did the community-member respondents $\left(\chi^{2}=7.67, \mathrm{df}=2, P<\right.$ $0.03)$. Of the community-members group, $8.1 \%$ thought everything was all right with this person, and $5.9 \%$ of them said they did not know. Only $14.8 \%$ of the leaders and $21.1 \%$ of the community-members group viewed this vignette as representing a mentally ill individual. Slightly more than half of the respondents from both of the groups thought the problem was serious.

Of the community-member respondents, $13.2 \%$ believed that the person described in the alcoholism vignette could overcome his problems on his own, in contrast to $4.9 \%$ of the leaders $\left(\chi^{2}=5.92, \mathrm{df}=2, P<0.05\right)$. The most common types of assistance suggested by the leaders, regardless of whether the vignette was perceived to be a men- something was wrong with the person described $\left(\chi^{2}=4.83, \mathrm{df}=1, P<0.03\right)$.

\section{Vignette 3: depression}

As in the two previous vignettes, almost all the respondents in both the community-leader and communitymember groups felt that something was wrong with the individual in the depression vignette. The communitymember respondents were more likely to view this person as mentally ill, $25.6 \%$, compared to the leader group, $18.6 \%\left(\chi^{2}=26.23, \mathrm{df}=3, P<0.00001\right)$.

Nevertheless, with the depression vignette, many respondents were uncertain as to the nature of the problem. Although not shown in table 4 , this was true for $22.6 \%$ of the persons in the community-member group and for $54.2 \%$ of the leaders. The community respondents were also more likely to view this person's problem as being serious $\left(\chi^{2}=7.70, \mathrm{df}=3, P<0.05\right)$. Most individuals, whether they thought the vignette represented someone with a mental illness or not, deemed that help was needed. Among those who did not view it as a mental illness, the leaders more often than the community members thought that help was required $\left(\chi^{2}=9.88, \mathrm{df}=4, P<0.05\right)$. Approximately $8.1 \%$ of the community-member respondents felt that the woman depicted could overcome the problem on her own. The most common sources of help suggested by the leaders, whether or not this was considered a mental disorder, were: psychologist, 34.5\%; psychiatrist, $15.5 \%$; social worker, $13.8 \%$; family or friends, $13.8 \%$; and family doctor, $8.1 \%$. Among the community members, the suggestions were: family or friends, $44.7 \%$; psychiatrist, $12.2 \%$; social worker, $8.1 \%$; family doctor, $8.1 \%$; and psychologist, $3.3 \%$.

Among the community-member respondents, females were more likely than males to state that the individual described in the depression vignette required help, $90.8 \%$ vs. $78.0 \%\left(\chi^{2}=3.91\right.$, $\mathrm{df}=1, P<0.05)$. Younger individuals were more likely to believe something was wrong with the individual described $(t=2.51, \mathrm{df}=132, P<0.012)$. No 
differences were found in the responses based on SES or between those with a history of an emotional disorder or not.

\section{Vignette 4: hyperactivity}

With the boy in the hyperactivity vignette, $87.1 \%$ of the leader group and $90.3 \%$ of the community-member group thought something was wrong; however, $6.7 \%$ of the community-member respondents said that nothing was wrong $\left(\chi^{2}=11.02, \mathrm{df}=2, P<0.005\right)$. The community respondents were more likely to see the behavior described as being consistent with mental illness $\left(\chi^{2}=11.47, \mathrm{df}=3, P<0.01\right)$. Fewer than half of the respondents viewed the problem described as being serious, but most agreed that help was needed. Among those who viewed the problem as a mental disorder, the communitymember respondents were more likely than the leaders to view mental hospitalization as a reasonable alternative $\left(\chi^{2}=5.24, \mathrm{df}=1, P<0.03\right)$. The type of help that each group viewed as appropriate varied. Regardless of whether they viewed the problem as psychiatric, the leaders endorsed: social worker, $26.2 \%$; psychologist, $24.6 \%$; psychiatrist, $18.0 \%$; family doctor, $11.5 \%$; family and friends, $8.2 \%$; and mental hospitalization, 3.3\%. The community-member group endorsed: family and friends, $33.3 \%$; mental hospitalization, $15.9 \%$; psychologist, $10.3 \%$; psychiatrist, $8.7 \%$; social worker, $8.7 \%$; and family doctor, $4.8 \%$.

Once again, among community members younger individuals viewed the problem presented as being more serious $(t=-2.02, \mathrm{df}=124, P<0.05)$. Those who were from the low SES were more likely to view the person described in the vignette as having mental illness, $38.8 \%$ vs. $27.7 \%$ for the middle SES and none among the high SES $\left(\chi^{2}=16.79\right.$, df $\left.=6, P<0.01\right)$. In addition, about half of the respondents from the low SES thought psychiatric hospitalization was appropriate in this situation: low SES, 52.9\%; middle SES, $8.0 \%$; and high SES, $0 \%\left(\chi^{2}=23.39\right.$, $\mathrm{df}=6, P<0.001)$. None of the persons who had a history of emotional disorder endorsed the use of a mental hospital for this vignette $\left(\chi^{2}=5.25, \mathrm{df}=1\right.$, $P<0.02)$.

\section{DISCUSSION}

The persons surveyed in Dominica narrowly defined a behavioral or emotional problem as mental illness. This was true for community members in general, as well as community leaders. Other than psychosis, the behavioral disturbances were generally not considered to be either mental illness or a serious problem. However, nearly everyone thought that each of the vignettes described someone who had something wrong and needed help.

In terms of such sociodemographic variables as gender, age, SES, or history of an emotional disorder, there were few differences among the community members in their responses to the vignettes. Consistently, however, younger individuals among the community respondents were more likely to believe something was wrong with the persons described in the vignettes. Interestingly, most respondents felt that if they or their family needed assistance with an emotional disorder, they would seek out the medical profession.

The community leaders appeared to have more difficulty than the community members did in identifying the vignettes as mental illness and even, at times, as serious problems. The low response rate among leaders could be interpreted as a negative attitude toward mental illness or a lack of acquaintance with surveys that require the respondent to return a questionnaire. This lack of mental-illness awareness among the community leaders was of particular concern, as nurses, teachers, and the police can play an integral role with individuals seeking care for their mental health problems. This limited awareness among Dominican gatekeepers may also reflect deficient knowledge of the efficacy of treatments for mental disorders (6). An alternative explanation might be the leaders' unwillingness to stigmatize individuals by labeling them as mentally ill.

The generalizability of this study is limited by the low response rate in both groups and the small sample size. Selection factors may also have biased the results in both groups. This issue is most notable in the leader group, where teachers made up just over half of the respondents.

The results of this study suggest that better public awareness of mental illness is needed among those directly linked to the pathways to care. The 1995 mental health survey suggested that serious mental illness was as much of a public health issue in Dominica as in other countries (1) and therefore cannot be ignored. This point is highlighted by a more recent survey among outpatients in the rural clinic at Marigot, in northeastern Dominica, which found a $28 \%$ prevalence of alcoholism-related symptoms, based on the CAGE questionnaire. ${ }^{7}$ Continued mental health promotion activities are needed in Dominica, including training gatekeepers to recognize mental illnesses and to properly direct persons seeking care.

Acknowledgments. This study was funded by the Pan American Health Organization.

\footnotetext{
Sharma D, Nasiiro R. Prevalence of alcoholism in a rural community in Dominica [conference presentation]. Commonwealth Caribbean Medical Research Council, Trinidad, 1996.
} 


\section{REFERENCES}

1. Pan American Health Organization. Health conditions in the Americas, 1998 edition, volume II. Washington, D.C.: PAHO; 1998. (Scientific publication 569).

2. Angermeyer MC, Matschinger H. Public attitude towards psychiatric treatment. Acta Psychiatr Scand 1996;94(5):326-336.

3. Phillips D. Rejection: a possible consequence of seeking help for mental disorders. Am Sociol Rev 1963;28:961-972.
4. Scheff $\mathrm{T}$. The labeling theory of mental illness. Am Sociol Rev 1974;39:444-452.

5. Levav I, Kohn R, Flaherty JA, Lerner Y, Aisenberg E. Mental health attitudes and practices of Soviet immigrants. Isr J Psychiatry Relat Sci 1990;27(3):131-144.

6. Jorm AF, Korten AE, Jacomb PA, Christensen $\mathrm{H}$, Rodgers B, Pollitt P. "Mental health literacy": a survey of the public's ability to recognise mental disorders and their beliefs about the effectiveness of treatment. Med J Aust 1997;166(4):182-186.

Manuscript received on 8 August 1999. Revised version accepted for publication on 21 December 1999.

RESUMEN Poco se sabe acerca de la percepción que tienen los habitantes del Caribe de habla inglesa en torno a las enfermedades mentales. El presente estudio se llevó a cabo en 1995 con el fin de determinar las actitudes, los conocimientos y los comportamientos

Actitudes hacia la salud mental en la Mancomunidad de Dominica relacionados con la búsqueda de atención por trastornos mentales en la Mancomunidad de Dominica. Se encuestaron dos grupos en la isla: 67 líderes comunitarios, entre los cuales se encontraban personal de enfermería, maestros y policías; y 135 miembros de la comunidad divididos en cinco estratos socioeconómicos que se colapsaron a tres para el análisis. Todos los encuestados tuvieron que identificar y sugerir maneras de tratar a las personas con psicosis, alcoholismo, depresión e hiperactividad infantil, tal como se describe en los relatos de casos ilustrativos. $\mathrm{Al}$ protagonista del relato sobre la psicosis le diagnosticaron enfermedad mental $84,0 \%$ de los líderes y $72 \%$ de los miembros de la comunidad. No obstante, en cada uno de los otros tres relatos, menos de $30 \%$ de los encuestados identificaron un trastorno mental. Solamente poco más de la mitad de los encuestados eran de la creencia de que la persona alcohólica estuviera afectada por un problema serio. Menos de la mitad opinaban que las personas con depresión o hiperactividad tuvieran un problema grave. Los líderes de la comunidad mostraron menor capacidad para reconocer un trastorno mental que los otros miembros de la comunidad. La tendencia más acentuada entre los encuestados fue la de remitir a un médico a miembros de la familia con trastornos mentales. En resumen, en Dominica hacen falta programas de educación sobre la enfermedad mental. La falta de conocimientos sobre las enfermedades de la mente por parte del personal de enfermería, los maestros y los policías produjo especial desconcierto, ya que estos profesionales tienen participación directa en las vías de acceso a la atención. 